Ильина Марина Алексеевна

студентка

Юридический институт ФГАОУ ВО «Южно-Уральский государственный университет (НИУ)»

г. Челябинск, Челябинская область Поспеев Константин Юрьевич канд. пед. наук, доцент ФГАОУ ВО «Южно-Уральский государственный университет (НИУ)»

г. Челябинск, Челябинская область

\title{
ОРГАНИЗАЦИОННО-ПРАВОВЫЕ И ТАКТИЧЕСКИЕ ОСНОВЫ
} ДЕЙСТВИЙ СОТРУДНИКОВ ОРГАНОВ ВНУТРЕННИХ ДЕЛ ПРИ ОБНАРУЖЕНИИ ВЗРЫВНЫХ УСТРОЙСТВ И ВЗРЫВЧАТЫХ

\section{ВЕЩЕСТВ. МЕРЫ БЕЗОПАСНОСТИ}

Аннотация: авторы статьи отмечают, что, как свидетельствует уголовно-процессуальная практика, в последние пятнадицать лет все чаще в качестве объектов оперативно-розыскного, следственного поиска выступают взрывчатые вещуества и взрывные устройства. Активный рост подобных преступлений наблюдается с 1990 года. Исследователи обращуют внимание на то, что взрыв как способ совершения преступлений стал получать все большее распространение, возрастающий технический уровень развития населения способствовал изготовлению самодельных взрывных устройств.

Ключевые слова: взрывные устройства, взрывчатые вещества, меры безопасности, сотрудник органов внутренних дел.

Человечество на протяжении сотен лет разрабатывало то, что сейчас называют современными взрывчатыми веществами и взрывными устройствами. Изначально был изобретен порох, который около трехсот лет использовался только для военных целей, однако у человека было стремление найти ему применение и 
в мирных целях. Аналогично открытию развитие также длилось не одно десятилетие.

Одной из ситуаций, связанной с риском и опасностью для жизни сотрудников ОВД, является проведение мероприятий по обнаружению взрывчатых веществ и взрывных устройств. Под личной безопасностью сотрудников органов внутренних дел подразумевается реальная защищенность жизни и здоровья человека, его целей, идеалов, ценностей, интересов от опасных воздействий в сфере профессиональной деятельности [1, с. 65].

Сотрудники ОВД должны быть готовы к решению многообразных и сложных задач, нередко решаемых в условиях дефицита времени, возникновения критических ситуаций, связанных с риском и опасностью для жизни. В то же время личная профессиональная безопасность сотрудника во многом зависит от него самого, от его общей профессиональной подготовленности и профессионального опыта. Кроме того, зарубежная и отечественная практика деятельности правоохранительных органов показывает, что важную роль в обеспечении безопасности сотрудников играет владение им специальной тактикой и методами действий в этом направлении [2, с. 43].

Для решения проблемы обеспечения безопасности сотрудников ОВД при обнаружении взрывных устройств и взрывчатых веществ необходимо при подготовке курсантов применять следующие методы и приемы:

- увеличение темпа деятельности;

- решение задачи при недостатке информации, помехах, с наличием элементов риска и опасности;

- введение в ход занятия непредвиденных препятствий и неожиданных усложнений;

- постановка задачи, требующей самостоятельного выбора одного способа решения из нескольких возможных;

- создание ситуаций, ведущих к частичной неудаче и требующих в дальнейшем повышения активности; 
- постановка задачи и создание ситуаций, требующих немедленного перехода к смелым, самостоятельным и организованным действиям;

- организация соревнования;

- составление моделей будущей деятельности от изменения ее внешних и внутренних условий;

- проведение практических занятий в условиях, максимально приближенных к реальным [3, с. 47].

Таким образом, использование данных рекомендаций в практике проведения учебного процесса в образовательных учреждениях МВД РФ позволит расширить педагогический арсенал средств и методов обучения и на его основе добиться более эффективного и всестороннего уровня готовности сотрудников к задачам по обнаружению взрывных устройств и взрывчатых веществ, что повысит уровень личной безопасности сотрудников ОВД.

\section{Список литературы}

1. Преображенский А.М. Специальная подготовка сотрудников органов внутренних дел: Учебное пособие. - М., 2012. - 65 с.

2. Топорков А.А. Собирание и исследование объектов взрывотехники. - М., 2011. - C. 43-44.

3. Тюрин В.А. Административно-правовые средства минимизации правонарушений и обеспечение собственной безопасности сотрудников полиции // Административное и муниципальное право. - 2012. - №6. - С. 47-48. 